\title{
Intestinal Spirochetosis mimicking inflammatory bowel disease in children
}

\author{
Rossana Helbling ${ }^{1}$, Maria-Chiara Osterheld ${ }^{2}$, Bernard Vaudaux ${ }^{3}$, Katia Jaton ${ }^{4}$ and Andreas Nydegger ${ }^{*}$
}

\begin{abstract}
Background: Intestinal spirochetosis is an unusual infection in children and its clinical significance in humans is uncertain. The presence of these microorganisms in humans is well-known since the late 1800's and was first described in 1967 by Harland and Lee by electron microscopy.

Case presentation: This article reports the findings of one pediatric case, review of the current literature, and an overview of therapeutic options.

Conclusion: A high degree of suspicion is required in cases presenting with abdominal pain, chronic diarrhoea and/or hematochezia associated with a normal endoscopic examination, thus emphasizing the importance of multiple biopsies throughout the colon.
\end{abstract}

Keywords: Intestinal spirochetosis, Brachyspira aalborgi, Brachyspira pilosicoli, Inflammatory bowel disease

\section{Background}

Spirochetes are well-known pathogens in veterinary medicine. They are associated with diarrheal illness, malnutrition and failure to thrive in a wide range of animals (swine, poultry, dogs, cats, opossum, non-human primates and guinea pigs) causing important economic losses [1].

The presence of intestinal spirochetes in human faeces has been recognized in the late 1800's [2]. The term intestinal spirochetosis was coined in 1967 by Harland and Lee who recognized spirochetes adherent to the cellular membrane of apical cells in the colonic epithelium [3]. This histological appearance is considered to be the hallmark of this infection.

The clinical significance of intestinal spirochetes in humans remains highly debated. Indeed, it is still unclear whether the finding of microorganisms coating the intestinal mucosal membrane is simply the reflection of a colonization process or the histological aspect of a disease [4].

\section{Case presentation}

A 13 year-old boy presented to our paediatric gastroenterology outpatient clinic with a one month history of

\footnotetext{
* Correspondence: Andreas.Nydegger@chuv.ch

${ }^{1}$ Pediatric Gastroenterology Unit, Department of Pediatrics, University of Lausanne, Centre Hospitalier Universitaire Vaudois, Rue du Bugnon 46, $\mathrm{CH}-1011$ Lausanne, Switzerland

Full list of author information is available at the end of the article
}

blood-stained diarrhoea, associated with urgency, weight loss of $1.5 \mathrm{~kg}$ and asthenia. He had no complaint of abdominal pain, fever or anorexia. The onset of symptoms coincided with the end of a 4-day history of acute gastroenteritis.

His past medical history revealed a recurrent aphthous stomatitis, and his family history was positive for celiac disease (one maternal cousin), irritable bowel syndrome (one paternal uncle) and bowel cancer (paternal grandfather). His growth parameters were normal and the physical examination revealed palpable stool masses in the left lower abdomen. Based on the clinical presentation, the differential diagnosis included inflammatory bowel disease, celiac disease, infectious colitis and intestinal polyp. Laboratory investigations showed no biological markers for inflammation (normal full blood count, ESR: $5 \mathrm{~mm} / \mathrm{h}$ and CRP: $0.28 \mathrm{mg} / \mathrm{l}$ ) or celiac disease. Fecal calprotectin was not measured. Stool cultures for conventional enteric pathogens (Salmonella, Shigella Campylobacter) were negative. Upper and lower endoscopy revealed mucosal oedema in the sigmoid and rectum, which was probably due to the required bowel preparation for colonoscopy. Histological examination on conventional hematoxylin and eosin stain of the colonic biopsy specimens revealed a fuzzy band on the surface of the enterocytes. This finding was highly suggestive of intestinal spirochetosis (Figure 1). Interestingly, no specific 

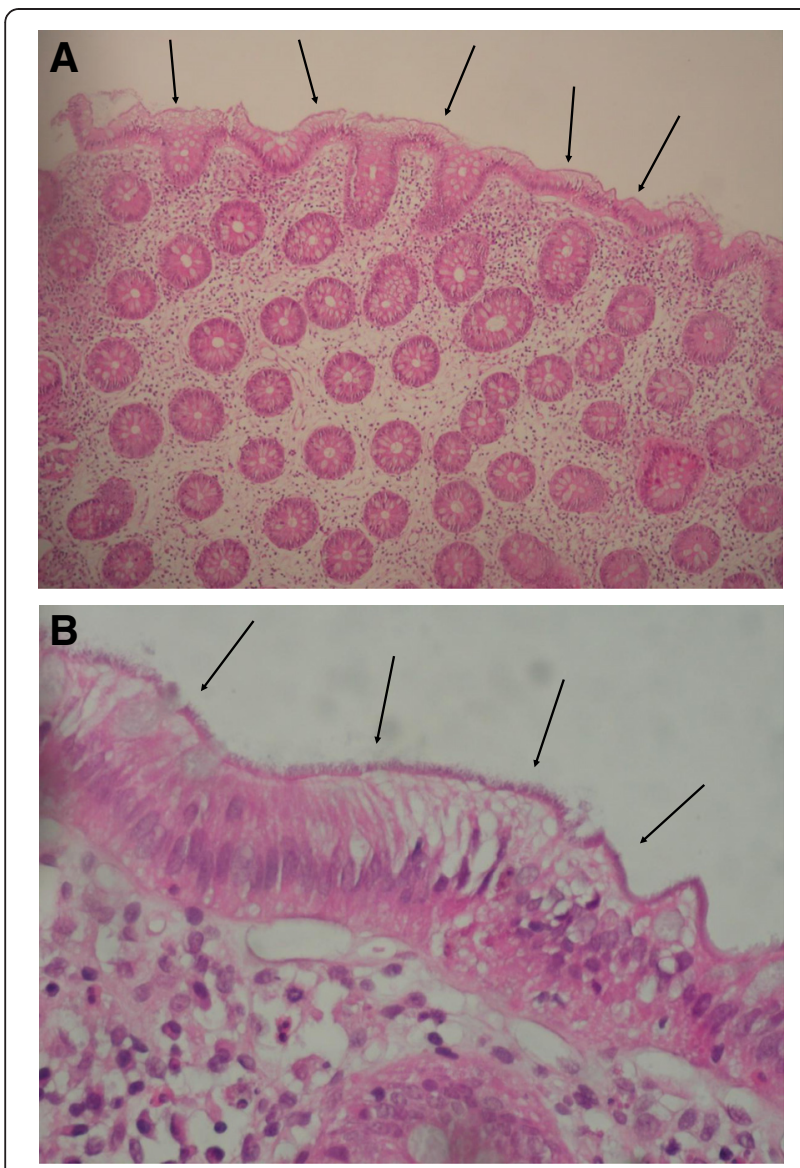

Figure 1 A: Hematoxylin and eosin stain of colon biopsy specimen showing multitudes of organisms along apical border of enterocytes, resembling a "false brush border" (H\&E, orig. mag. x10). B: Colonic mucosa with thick hematoxyphilic fringe on the brush border of the luminal surface (H\&E, orig. mag. X40).

inflammatory reaction or lesions were observed. The diagnosis of intestinal spirochetosis was confirmed by Fluorescence in situ hybridization (FISH), confirming the presence of Brachyspira aalborgi (Figure 2).

On the assumption that most intestinal spirochetes (obtained from veterinary specimens) are susceptible to amoxicillin, the patient was initially treated with this antibiotic (30mg/kg/day, divided into 3 doses) during 14 days, with subsequent cessation of rectal bleeding but persistent mucous diarrhoea. Additional treatment with metronidazole $(30 \mathrm{mg} / \mathrm{kg} /$ day, divided into 3 doses) for 10 days resulted in complete resolution of symptoms, therefore, no follow-up endoscopy was performed.

\section{Methods}

A Medline search was performed for all studies published from 1993 to December 2011 using the Medical Subject Heading and keywords: "intestinal spirochetosis" and "all child (0-18 years)". Articles in any other language than English have been excluded. All studies retrieved were considered and data from relevant' ones were presented in Table 1 and discussed in the text.

\section{Results}

To the best of our knowledge, there were 8 articles describing a total of 25 paediatric cases of intestinal spirochetosis [5-12]. Three patients presented spirochetes on histopathological examination of a resected appendix without endoscopy. Sex distribution was similar (13 girls, 12 boys) with a median age of 9.5 years (range: 2-17 years). Patients mainly presented with abdominal pain, diarrhoea and rectal bleeding with, apart from aspecific signs of mild inflammation, normal endoscopic findings. Table 1 summarizes those 25 patients with respect to their age, symptoms, endoscopic and histological findings and treatment. Many patients had more than one treatment due to persistence of symptoms, although metronidazole seemed to be the favourite therapeutic agent. Two out of 5 patients improved without treatment and the overall outcome was favourable in 17 patients $(68 \%)$.

\section{Discussion}

Adhesion of spirochetes to the brush border mucosa resulting in its thickening as seen on light microscopy can be observed worldwide in both children and adults [1]. Diagnosis is usually made by histopathology.

Spirochetes are currently divided into three phylogenetic groups: Spirochaetaceae including Borrelia, Spirochaeta, Spironema and Treponema; Leptospiraceae including Leptonema and Leptospira; and finally Brachyspiraceae containing the intestinal spirochetes of Brachyspira (Serpulina) [1]. Brachyspira aalborgi (B. aalborgi) and Brachyspira pilosicoli (B. pilosicoli), the two members of Brachyspiraceae family, are both described in

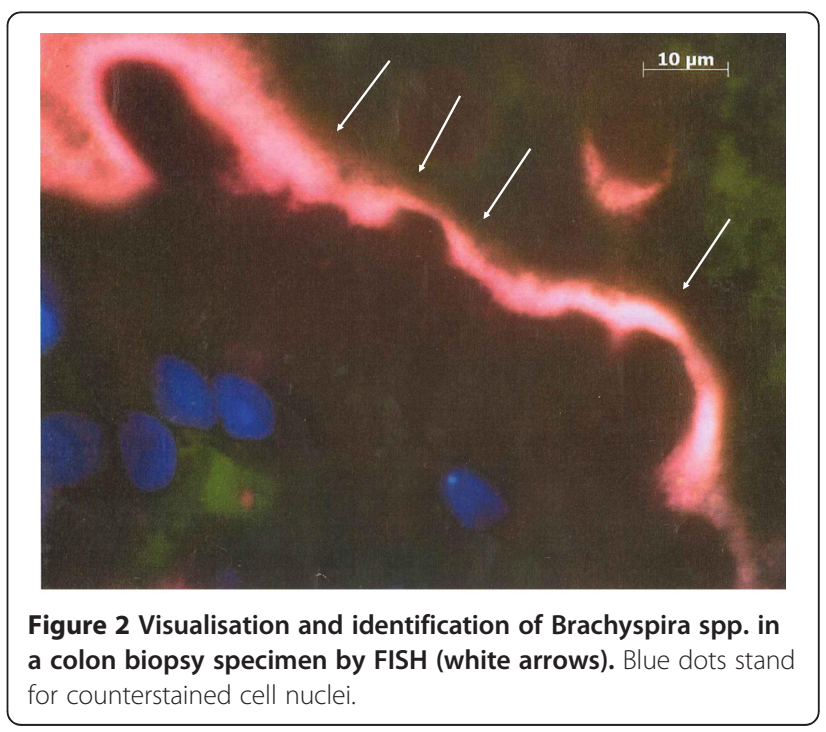


Table 1 Description of 25 cases of pediatric intestinal spirochetosis (IS)

\begin{tabular}{|c|c|c|c|c|c|c|c|}
\hline Ref. & Age (y) & Sex & $\begin{array}{l}\text { Signs and } \\
\text { Symptoms }\end{array}$ & $\begin{array}{l}\text { Endoscopic } \\
\text { findings }\end{array}$ & $\begin{array}{l}\text { Histologic } \\
\text { findings }\end{array}$ & Treatment & Comments \\
\hline \multirow[t]{3}{*}{ [5] } & 6 & $\mathrm{~F}$ & $\begin{array}{l}\text { Rectal bleeding, } \\
\text { abdominal pain, } \\
\text { pruritus ani }\end{array}$ & Normal & $\begin{array}{l}\text { IS and mild } \\
\text { inflammation }\end{array}$ & Piperazine & Improvement \\
\hline & 2 & M & $\begin{array}{l}\text { Intermittent } \\
\text { bloody diarrhoea }\end{array}$ & Distal colitis & $\begin{array}{l}\text { IS and mild to } \\
\text { moderate infiltration } \\
\text { with inflammatory cells }\end{array}$ & $\begin{array}{l}\text { Mebendazole } \\
\text { (Ascaris in stool) }\end{array}$ & Improvement \\
\hline & 13 & M & $\begin{array}{l}\text { Recurrent fever, } \\
\text { abdominal pain, } \\
\text { joint pain, mouth } \\
\text { and penile ulcers }\end{array}$ & Normal & $\begin{array}{l}\text { IS and mild patchy } \\
\text { inflammation }\end{array}$ & No treatment & $\begin{array}{l}\text { No follow-up } \\
\text { information }\end{array}$ \\
\hline \multirow[t]{3}{*}{ [6] } & \multirow[t]{2}{*}{7.5} & \multirow[t]{2}{*}{ M } & \multirow{2}{*}{$\begin{array}{l}\text { Periumbilical pain, } \\
\text { frequent bloody stools, } \\
\text { urgency, poor appetite } \\
\text { and weight loss }\end{array}$} & \multirow{2}{*}{$\begin{array}{l}\text { Mild rectal } \\
\text { granularity }\end{array}$} & \multirow[t]{2}{*}{ IS } & 1) Metronidazole & \multirow{2}{*}{$\begin{array}{l}\text { Persistence of } \\
\text { diarrhea; } \\
\text { eradication on } \\
\text { endoscopic } \\
\text { follow-up at } \\
6 \text { months }\end{array}$} \\
\hline & & & & & & 2) Neomycine & \\
\hline & 8 & $\mathrm{~F}$ & $\begin{array}{l}\text { Acute abdominal pain, } \\
\text { vomiting and fever }\end{array}$ & Not done & $\begin{array}{l}\text { IS in resected } \\
\text { appendix }\end{array}$ & No treatment & Improvement \\
\hline \multirow[t]{5}{*}{ [7] } & 12 & M & $\begin{array}{l}\text { Intermittent vomiting, } \\
\text { diarrhoea, weight loss, } \\
\text { headaches and fatigue }\end{array}$ & Normal & $\begin{array}{l}\text { IS and mild } \\
\text { focal colitis }\end{array}$ & $\begin{array}{l}\text { Metronidazole and } \\
\text { Amoxicillin ( } 7 \text { days) }\end{array}$ & Improvement \\
\hline & \multirow[t]{2}{*}{12} & \multirow[t]{2}{*}{ M } & \multirow{2}{*}{$\begin{array}{l}\text { Recurrent } \\
\text { abdominal } \\
\text { pain }\end{array}$} & \multirow[t]{2}{*}{ Normal } & \multirow{2}{*}{$\begin{array}{l}\text { IS and mild focal } \\
\text { cryptitis in the } \\
\text { caecum }\end{array}$} & $\begin{array}{l}\text { 1) Penicillin } \vee \text { and } \\
\text { Metronidazole ( } 7 \text { days) }\end{array}$ & \multirow{2}{*}{$\begin{array}{l}\text { Persistence of } \\
\text { symptoms and IS; } \\
\text { after second course } \\
\text { of Metronidazole } \\
\text { eradication and } \\
\text { improvement }\end{array}$} \\
\hline & & & & & & $\begin{array}{l}\text { 2) Metrodidazole } \\
\text { (800mg 3x/d for } 7 \text { days) }\end{array}$ & \\
\hline & 16 & $\mathrm{~F}$ & $\begin{array}{l}\text { Recurrent colicky } \\
\text { right upper quadrant } \\
\text { pain }\end{array}$ & Normal & is & $\begin{array}{l}\text { Metronidazole and } \\
\text { Amoxicillin (10 days) }\end{array}$ & Improvement \\
\hline & 9 & $F$ & $\begin{array}{l}\text { Intermittent diarrhoea } \\
\text { and rectal bleeding }\end{array}$ & Normal & is & $\begin{array}{l}\text { Metronidazole and } \\
\text { Amoxicillin (10 days) }\end{array}$ & Improvement \\
\hline \multirow[t]{9}{*}{ [8] } & 5 & $F$ & $\begin{array}{l}\text { Abdominal pain, } \\
\text { diarrhoea and rectal } \\
\text { bleeding }\end{array}$ & $\begin{array}{l}\text { Rectal oedema } \\
\text { and enterobiasis }\end{array}$ & IS & $\begin{array}{l}\text { Erythromycin } \\
\text { (40mg/kg/d for } 10 \text { days) }\end{array}$ & $\begin{array}{l}\text { Rectal bleeding } \\
\text { ceased but abdominal } \\
\text { pain recurred, } \\
\text { no follow-up }\end{array}$ \\
\hline & 7 & M & $\begin{array}{l}\text { Abdominal pain } \\
\text { and diarrhoea }\end{array}$ & Slight proctitis & is & $\begin{array}{l}\text { Doxycycline }(200 \mathrm{mg} \text { day } 1 \\
\text { then } 100 \mathrm{mg} / \mathrm{d} \text { for } 8 \text { days })\end{array}$ & $\begin{array}{l}\text { Persistence of } \\
\text { abdominal pain } \\
\text { despite endoscopic } \\
\text { eradication }\end{array}$ \\
\hline & 4 & F & $\begin{array}{l}\text { Mucus and bloody } \\
\text { stools }\end{array}$ & $\begin{array}{l}\text { Proctitis, } \\
\text { juvenile polyp }\end{array}$ & IS & $\begin{array}{l}\text { Clarithromycin } \\
(50 \mathrm{mg} / \mathrm{kg} / \mathrm{d} \text { for } \\
10 \text { days })\end{array}$ & Improvement \\
\hline & 10 & $F$ & $\begin{array}{l}\text { Diarrhoea and } \\
\text { rectal bleeding }\end{array}$ & $\begin{array}{l}\text { Rectal hyperaemic } \\
\text { membranes }\end{array}$ & IS & Clarithromycin & Improvement \\
\hline & \multirow[t]{2}{*}{13} & \multirow[t]{2}{*}{ M } & \multirow{2}{*}{$\begin{array}{l}\text { Abdominal pain, } \\
\text { nausea and weight } \\
\text { loss }\end{array}$} & \multirow{2}{*}{$\begin{array}{l}\text { Slight } \\
\text { inflammation } \\
\text { of rectum }\end{array}$} & \multirow[t]{2}{*}{$\begin{array}{l}\text { IS and HP- positive } \\
\text { gastritis }\end{array}$} & $\begin{array}{l}\text { 1) Clarithromycin and } \\
\text { Amoxicillin }\end{array}$ & \multirow{2}{*}{$\begin{array}{l}\text { Persistence of IS, } \\
\text { eradication after } \\
\text { Clarithromycin } \\
\text { and Metronidazole }\end{array}$} \\
\hline & & & & & & $\begin{array}{l}\text { 2) Clarithromycin and } \\
\text { Metronidazole ( } 500 \mathrm{mg} 2 x / \mathrm{d} \\
\text { and } 400 \mathrm{mg} 3 x / \mathrm{d} 7 \text { days) }\end{array}$ & \\
\hline & \multirow[t]{2}{*}{8} & \multirow[t]{2}{*}{ M } & \multirow{2}{*}{$\begin{array}{l}\text { Recurrent } \\
\text { abdominal } \\
\text { pain }\end{array}$} & \multirow[t]{2}{*}{ Juvenile polyp } & \multirow{2}{*}{$\begin{array}{l}\text { IS and low-grade } \\
\text { chronic } \\
\text { inflammation }\end{array}$} & 1) Penicillin V & \multirow{2}{*}{$\begin{array}{l}\text { Improvement after } \\
\text { Erythromycin }\end{array}$} \\
\hline & & & & & & $\begin{array}{l}\text { 2) Erythromycin ( } 40-50 \mathrm{mg} / \mathrm{kg} / \mathrm{d} \\
\text { for } 10 \text { days) }\end{array}$ & \\
\hline & 15 & $\mathrm{~F}$ & $\begin{array}{l}\text { Abdominal pain and } \\
\text { rectal bleeding }\end{array}$ & Normal & is & $\begin{array}{l}\text { Clarithromycin ( } 500 \mathrm{mg} 2 \mathrm{2x} / \mathrm{d} \\
\text { for } 14 \text { days) }\end{array}$ & $\begin{array}{l}\text { Improvement but } \\
\text { persistence of } \\
\text { rectal bleeding; } \\
\text { absence of IS on } \\
\text { follow-up rectoscopy }\end{array}$ \\
\hline
\end{tabular}


Table 1 Description of 25 cases of pediatric intestinal spirochetosis (IS) (Continued)

\begin{tabular}{|c|c|c|c|c|c|c|c|}
\hline & 14 & $\mathrm{~F}$ & Abdominal pain & Normal & IS & $\begin{array}{l}\text { Metronidazole ( } 400 \mathrm{mg} 3 \times / \mathrm{d} \\
\text { for } 10 \text { days) }\end{array}$ & $\begin{array}{l}\text { No improvement; } \\
\text { absence of IS on } \\
\text { follow-up } \\
\text { colonoscopy }\end{array}$ \\
\hline [9] & 9 & M & $\begin{array}{l}\text { Recurrent abdominal } \\
\text { pain, diarrhea and } \\
\text { rectal bleeding }\end{array}$ & $\begin{array}{l}\text { Mild erythema } \\
\text { of rectal mucosa }\end{array}$ & $\begin{array}{l}\text { IS and } \\
\text { hypereosinophilia }\end{array}$ & $\begin{array}{l}\text { Erythromycin }(40 \mathrm{mg} / \mathrm{kg} / \mathrm{d} \\
\text { for } 10 \text { days) }\end{array}$ & Improvement \\
\hline [10] & 9 & M & $\begin{array}{l}\text { Rectal bleeding, } \\
\text { diarrhea, tenesmus, } \\
\text { flatulence and weight } \\
\text { loss }\end{array}$ & Normal & $\begin{array}{l}\text { IS and mild epithelial } \\
\text { reactive changes }\end{array}$ & No treatment & Improvement \\
\hline [11] & 4 & $\mathrm{~F}$ & $\begin{array}{l}\text { Abdominal discomfort, } \\
\text { rectal bleeding and } \\
\text { weight loss }\end{array}$ & $\begin{array}{l}\text { Mucosal erosions, } \\
\text { hyperemia, } 2 \\
\text { juvenile } \\
\text { polyps }\end{array}$ & $\begin{array}{l}\text { IS and inflammatory } \\
\text { infiltrate }\end{array}$ & Metronidazole & Improvement \\
\hline \multirow[t]{7}{*}{ [12] } & \multirow[t]{3}{*}{11} & \multirow[t]{3}{*}{$F$} & \multirow{3}{*}{$\begin{array}{l}\text { Intermittent } \\
\text { abdominal } \\
\text { pain and rectal } \\
\text { bleeding }\end{array}$} & \multirow[t]{3}{*}{ Normal } & \multirow[t]{3}{*}{ IS } & $\begin{array}{l}\text { 1)Metronidazole } \\
\text { (250mg 3x/d) }\end{array}$ & \multirow{3}{*}{$\begin{array}{l}\text { No improvement, } \\
\text { additional course } \\
\text { of Metronidazole and } \\
\text { Vancomycin with } \\
\text { persistence of IS, } \\
\text { no follow-up } \\
\text { information }\end{array}$} \\
\hline & & & & & & $\begin{array}{l}\text { 2) Metronidazole }(1000 \mathrm{mg} / \mathrm{d} \\
\text { for } 2 \text { months and } 750 \mathrm{mg} / \mathrm{d} \\
\text { for } 14 \text { days) }\end{array}$ & \\
\hline & & & & & & 3) Vancomycin (7 days) & \\
\hline & 6 & M & $\begin{array}{l}\text { Stomach cramps, } \\
\text { rectal bleeding, } \\
\text { intermittent diarrhea, } \\
\text { rectal prolapse }\end{array}$ & Normal & IS & $\begin{array}{l}\text { Metronidazole } \\
(250 \mathrm{mg} 2 \times / \mathrm{d})\end{array}$ & $\begin{array}{l}\text { Improvement, } \\
\text { but alternating } \\
\text { constipation with } \\
\text { watery diarrhea and } \\
\text { rectal prolapse }\end{array}$ \\
\hline & 17 & $\mathrm{~F}$ & $\begin{array}{l}\text { Recurrent } \\
\text { abdominal pain, } \\
\text { nausea, vomiting }\end{array}$ & Normal & $\begin{array}{l}\text { IS and mild eosinophilic } \\
\text { inflammatory infiltrate }\end{array}$ & No treatment & $\begin{array}{l}\text { No follow-up } \\
\text { information }\end{array}$ \\
\hline & 11 & $\mathrm{~F}$ & $\begin{array}{l}\text { Right lower } \\
\text { quadrant pain }\end{array}$ & Not done & $\begin{array}{l}\text { Appendicitis and IS in } \\
\text { resected appendix }\end{array}$ & $\begin{array}{l}\text { Cefoxitin }(30 \mathrm{mg} / \mathrm{kg} / \text { dose, } \\
4 \text { doses) }\end{array}$ & $\begin{array}{l}\text { No follow-up } \\
\text { information }\end{array}$ \\
\hline & 10 & M & $\begin{array}{l}\text { Periumbilical and } \\
\text { epigastric pain, } \\
\text { nausea, fever }\end{array}$ & Not done & $\begin{array}{l}\text { Appendicitis and IS in } \\
\text { resected appendix }\end{array}$ & No treatment & $\begin{array}{l}\text { No follow-up } \\
\text { information }\end{array}$ \\
\hline
\end{tabular}

humans and are considered as cause of human intestinal spirochetosis [13]. The anaerobic weakly $\beta$ haemolytic intestinal spirochete $B$. aalborgi, was first isolated in 1982 in the stool of a patient from Denmark [14], whereas B. pilosicoli is responsible for colitis and typhlytis in pigs, poultry and other species, acting more as zoonotic agent [15]. Since 1997, Brachyspira spp. have been included in the list of human enteropathogenic bacteria [16]. These two spirochetes are slow growing fastidious anaerobes and require specific media, with estimated growth times of 6 days for B. pilosicoli and up to 2 weeks for B.aalborgi [17]. Morphologically, they are coiled Gram-negative bacilli and are mobile in liquid environment due to the presence of flagella. Generally they are considered non invasive microorganisms but systemic spread of B.pilosicoli has been documented by culture of blood specimens obtained from critically ill patients [18]. Concomitant infection by B.aalborgi and B.pilosicoli is described but rare [19]. These spirochetes are susceptible to different antibiotics, such as metronidazole, meropenem, chloramphenicol, ceftriaxone and tetracycline, whereas a $60 \%$ resistance rate to ciprofloxacine has been observed [20]. Little is known about the way of transmission, but it seems likely to occur by faecal-oral route (contaminated water, colonized/infected faeces) [19]. Due to the higher prevalence in homosexual men, sexual transmission has been suggested as well [21]. Possible co-infection with others microorganisms like Helicobacter pylori, Enterobius vermicularis, Shigella flexneri, Neisseria gonorrhoeae, Entamoeba histolytica, Blastocystis hominis, and Ascaris is possible, rendering clinical significance difficult [2].

The prevalence varies considerably in geography and immune condition. In developed countries for example ranges between 1.1-5\% can be observed, with an increase in homosexual men and HIV positive patients [1]. In a recent study from Japan the incidence of human intestinal spirochetosis in patients aged from 35 to 75 years was $0.4 \%$ and therefore lower than in Western countries [22]. The paucity of epidemiologic data is probably due to several reasons: firstly: the endoscopist not always takes routine multiple biopsies in healthy looking 
mucosa; secondly: the pathologist actively has to look for spirochetes and can easily miss them if not familiar with its appearance and thirdly: it is not a routine diagnosis by microbiologist either [11].

In most cases, intestinal spirochetosis is asymptomatic and presents as accidental findings during a screening colonoscopy for other reasons [23]. However, infected children usually complain of persistent diarrhoea, rectal bleeding, constipation, abdominal pain, weight loss, failure to thrive, nausea and lack of appetite [24]. The severity of disease can vary from asymptomatic colonisation to invasive and rapidly fatal progression [25], but there appears to be no correlation with degree of immunodeficiency in HIV positive patient and the extent of disease [1]. Due to this unspecific presentation, differential diagnosis should include inflammatory bowel disease, infectious, ischemic or pseudomembranous colitis and rectocolic carcinoma [24]. Colonic involvement is documented from distal to proximal, including rectum and appendix [26]. Mucosal appearance on endoscopy is not helpful in making the diagnosis, as it can be normal, polypoid, and erythematous, or just show unspecific lesions [27]. In a large Australian case series of 113 adult patients presenting with intestinal spirochetosis, 90 percent of colorectal specimens showed no morphological alterations, whereas the remaining cases had other possible causes for inflammation [23]. Histological appearance of a diffuse blue-fringe (better seen in hematoxylin-eosin or a silver stain), 3-6 $\mathrm{m}$ thick, along the border of intestinal epithelial layer, referred to as the « false brush border » is highly suggestive [1]. The surrounding cytostructure may show inflammation with slight oedema, infiltrate of monocytes, lymphocytes, plasma cells and neutrophils in the lamina propria, as well as elongated and hyperplastic crypts [28]. On electron microscopy, spirochetes are attached perpendicularly to the epithelial membrane of the enterocytes and the microvilli appear shortened or depleted [3]. Analysis of specimens from infected individuals even though rare has shown spirochetal invasion of colonic epithelial cells, macrophages, goblet cells and Schwann cells [29]. Histologically it is not possible to distinguish B.pilosicoli from B.aalborgi, therefore genetic methods have been developed in order to identify Brachyspira species from stool or tissue samples. Fluorescent in situ hybridization using oligonucleotide probes targeting $16 \mathrm{~S}$ or $23 \mathrm{~S}$ rRNA of B. aalborgi and B. pilosicoli allow visualisation and identification of this microorganism [28].

Treatment strategies have been proposed for intestinal spirochetosis eradication, including macrolids and clindamycin, but metronidazole seems to be the drug of choice, with a dose regimen of $500 \mathrm{mg} 3$ times a day for 10 days in adults and $15 \mathrm{mg}$ per $\mathrm{kg}$ bodyweight 3 times per day for 5 days in children [19]. At the moment, there is lack of evidence regarding the most effective antibiotic agent as treatment response is variable and sometimes even ineffective supporting the hypothesis that these microorganisms are harmless commensals in humans, rendering specific treatment questionable [1]. Spontaneous recovery has been described after a prolonged period for up to 8 months [8].

\section{Conclusions}

Intestinal spirochetosis may be more frequent than suspected and clinicians should take into account this disease, especially in case of persistent diarrhoea without any other reason. Diagnosis can only be made by an experienced pathologist and microbiologist and requires a lower endoscopy with multiple biopsies throughout the colon.

\section{Competing interests}

The authors declare that they have no competing interests.

\section{Authors' contributions}

$\mathrm{RH}$ drafted the manuscript and collected data related to the subject; BV was involved in revising critically the manuscript and helped to draft the manuscript. AN participated in the design of the manuscript and the coordination. All authors read and approved the final manuscript.

\section{Acknowledgements}

Written consent was obtained from the patient's parents for publication of this case report.

\section{Author details}

${ }^{1}$ Pediatric Gastroenterology Unit, Department of Pediatrics, University of Lausanne, Centre Hospitalier Universitaire Vaudois, Rue du Bugnon 46, CH-1011 Lausanne, Switzerland. ${ }^{2}$ Institute of Pathology, University of Lausanne, Centre Hospitalier Universitaire Vaudois, Rue du Bugnon 48, $\mathrm{CH}-1011$ Lausanne, Switzerland. ${ }^{3}$ Pediatric Infectious Disease Unit, Department of Pediatrics, University of Lausanne, Centre Hospitalier Universitaire Vaudois, Rue du Bugnon 46, CH-1011 Lausanne, Switzerland. ${ }^{4}$ Institute of Microbiology, University of Lausanne, Centre Hospitalier Universitaire Vaudois, Rue du Bugnon 48, CH-1011 Lausanne, Switzerland.

Received: 6 July 2012 Accepted: 8 October 2012

Published: 16 October 2012

\section{References}

1. Tsinganou E, Gebbers JO: Human intestinal spirochetosis--a review. German medical science: GMS e-journal 2010, 8:Doc01.

2. van Mook WN, Koek GH, van der Ven AJ, Ceelen TL, Bos RP: Human intestinal spirochaetosis: any clinical significance? Eur J Gastroenterol Hepatol 2004, 16(1):83-87.

3. Harland WA, Lee FD: Intestinal spirochaetosis. British Medical Journal 1967, 3(5567):718-719.

4. Nielsen RH, Orholm M, Pedersen JO, Hovind-Hougen K, Teglbjaerg PS, Thaysen EH: Colorectal spirochetosis: clinical significance of the infestation. Gastroenterology 1983, 85(1):62-67.

5. da Cunha-Ferreira RM, Phillips AD, Stevens CR, Hudson MJ, Rees HC, WalkerSmith JA: Intestinal spirochaetosis in children. J Pediatr Gastroenterol Nutr 1993, 17(3):333-336.

6. White J, Roche D, Chan YF, Mitchell EA: Intestinal spirochetosis in children: report of two cases. Pediatric pathology / affiliated with the International Paediatric Pathology Association 1994, 14(2):191-199.

7. Heine RG, Ward PB, Mikosza AS, Bennett-Wood V, Robins-Browne RM, Hampson DJ: Brachyspira aalborgi infection in four Australian children. J Gastroenterol Hepatol 2001, 16(8):872-875. 
8. Marthinsen L, Willen R, Carlen B, Lindberg E, Varendh G: Intestinal spirochetosis in eight pediatric patients from Southern Sweden. APMIS: Acta Pathologica, Microbiologica, et immunologica Scandinavica 2002, 110(7-8):571-579.

9. Nodit L, Parizhskaya M: Intestinal spirochetosis. Arch Pathol Lab Med 2004, 128(7):823-824.

10. King NR, Fidda N, Gourley G: Colorectal spirochetosis in a child with rectal bleeding: case report and literature review. J Pediatr Gastroenterol Nutr 2005, 41(5):673-675.

11. Calderaro A, Bommezzadri S, Gorrini C, Piccolo G, Peruzzi S, Villanacci V, Zambelli C, Dettori G, Chezzi C: Infective colitis associated with human intestinal spirochetosis. J Gastroenterol Hepatol 2007, 22(11):1772-1779.

12. Carpentieri DF, Souza-Morones S, Gardetto JS, Ross HM, Downey K, Ingebo $\mathrm{K}$, Siaw E: Intestinal spirochetosis in children: five new cases and a 20year review of the literature. Pediatr Dev Pathol 2010, 13(6):471-475.

13. Paster BJ, Dewhirst FE: Phylogenetic foundation of spirochetes. J Mol Microbiol Biotechnol 2000, 2(4):341-344.

14. Hovind-Hougen K, Birch-Andersen A, Henrik-Nielsen R, Orholm M, Pedersen JO, Teglbjaerg PS, Thaysen EH: Intestinal spirochetosis: morphological characterization and cultivation of the spirochete Brachyspira aalborgi gen. nov., sp. nov. J Clin Microbiol 1982, 16(6):1127-1136.

15. Hampson DJ, Oxberry SL, La T: Potential for zoonotic transmission of Brachyspira pilosicoli. Emerg Infect Dis 2006, 12(5):869-870.

16. Bruckner DA, Colonna P: Nomenclature for aerobic and facultative bacteria. Clinical infectious diseases: an official publication of the Infectious Diseases Society of America 1997, 25(1):1-10.

17. Mikosza AS, La T, de Boer WB, Hampson DJ: Comparative prevalences of Brachyspira aalborgi and Brachyspira (Serpulina) pilosicoli as etiologic agents of histologically identified intestinal spirochetosis in Australia. J Clin Microbiol 2001, 39(1):347-350.

18. Bait-Merabet L, Thille A, Legrand P, Brun-Buisson C, Cattoir V: Brachyspira pilosicoli bloodstream infections: case report and review of the literature. Ann Clin Microbiol Antimicrob 2008, 7:19.

19. Calderaro A, Gorrini C, Peruzzi S, Piccolo G, Dettori G, Chezzi C: Occurrence of human intestinal spirochetosis in comparison with infections by other enteropathogenic agents in an area of the Northern Italy. Diagn Microbiol Infect Dis 2007, 59(2):157-163.

20. Brooke CJ, Hampson DJ, Riley TV: In vitro antimicrobial susceptibility of Brachyspira pilosicoli isolates from humans. Antimicrob Agents Chemother 2003, 47(7):2354-2357.

21. Law CL, Grierson JM, Stevens SM: Rectal spirochaetosis in homosexual men: the association with sexual practices, HIV infection and enteric flora. Genitourinary Medicine 1994, 70(1):26-29.

22. Tanahashi J, Daa T, Gamachi A, Kashima K, Kondoh Y, Yada N, Yokoyama S: Human intestinal spirochetosis in Japan; its incidence, clinicopathologic features, and genotypic identification. Modern pathology: an official journal of the United States and Canadian Academy of Pathology, Inc 2008, 21(2):76-84.

23. Carr NJ, Mahajan H, Tan KL, Sharma R: The histological features of intestinal spirochetosis in a series of 113 patients. Int I Surg Pathol 2010, 18(2):144-148

24. Peruzzi S, Gorrini C, Piccolo G, Calderaro A, Dettori G, Chezzi C: Human intestinal spirochaetosis in Parma: a focus on a selected population during 2002-2005. Acta bio-medica: Atenei Parmensis 2007, 78(2):128-132.

25. Korner $\mathrm{M}$, Gebbers JO: Clinical significance of human intestinal spirochetosis-a morphologic approach. Infection 2003, 31(5):341-349

26. Yang M, Lapham R: Appendiceal spirochetosis. Southern Medical Journal 1997, 90(1):30-32.

27. Alsaigh N, Fogt F: Intestinal spirochetosis: clinicopathological features with review of the literature. Colorectal disease: the official journal of the Association of Coloproctology of Great Britain and Ireland 2002, 4(2):97-100.

28. Schmiedel D, Epple HJ, Loddenkemper C, Ignatius R, Wagner J, Hammer B, Petrich A, Stein H, Gobel UB, Schneider T, et al: Rapid and accurate diagnosis of human intestinal spirochetosis by fluorescence in situ hybridization. J Clin Microbiol 2009, 47(5):1393-1401.

29. Antonakopoulos G, Newman J, Wilkinson M: Intestinal spirochaetosis: an electron microscopic study of an unusual case. Histopathology 1982, 6(4):477-488.

doi:10.1186/1471-2431-12-163

Cite this article as: Helbling et al:: Intestinal Spirochetosis mimicking inflammatory bowel disease in children. BMC Pediatrics 2012 12:163.

\section{Submit your next manuscript to BioMed Central and take full advantage of:}

- Convenient online submission

- Thorough peer review

- No space constraints or color figure charges

- Immediate publication on acceptance

- Inclusion in PubMed, CAS, Scopus and Google Scholar

- Research which is freely available for redistribution 